Z. klin. Chem. u. klin. Biochem.

10. Jg. 1972 , S. $17-20$

\title{
A New Automated Determination of Uric Acid
}

\author{
By K. BreebaArt and A. M. F. H. HaAn \\ Clinical laboratory, R. K. Ziekenbuis Mariastichting, Haarlem, The Netherlands
}

(Eingegangen am 1. Juni/24. August 1971)

\begin{abstract}
A new method for the automated determination of uric acid in serum and urine, using the Auto Analyzersystem, is reported. This method is based on the colour reaction of uric acid with phosphotungstic acid in an alkaline solution. The results obtained by this method are satisfactory and reliable.

It is considered that the method can be useful as a routine test for uric acid in clinical laboratories.

Es wird eine neue automatische Bestimmungsmethode für Harnsäure in Körperflüssigkeiten mit dem Auto Analyzer beschrieben. Diese Methode basiert auf der kolorimetrischen Reaktion von Harnsäure mit Phosphor-Molybdänsäure im alkalischen Milieu.

Die mit dieser Methode erhaltenen Resultate sind sehr befriedigend und sehr zuverlässig.

Diese rasch durchführbare Methode erwies sich als sehr geeignet zur Routinebestimmung von Harnsäure.
\end{abstract}

Uric acid is commonly determined in biological fluids by two methods. One is based on measuring the blue colour produced by its reaction with reagents containing phosphotungstic acid under conditions which minimize interference by other reducing substances, the other one is the enzymatic estimation of uric acid with uricase $(1,2)$.

Since the first method is best suited for automation, a procedure for the Auto Analyzersystem has been developed in our laboratory.

As the colorimetric methods have been criticized for their lack of specificity $(3,4)$, the influence of factors which possibly affect the reaction was studied. Recovery tests of uric acid were made. The baseline drift, the noise, the sensitivity, and the specimen interaction were found to lie within acceptable limits for routine determinations in a clinical laboratory (5).

A stastical quality control has been made from data obtained from one thousand samples during eight months.

\section{Material and Methods}

\section{Apparatus}

Technicon Auto Analyzer standard performance (Mark I). For flow diagram see figure 1.

\section{Reagents}

Reagent $A: 60.0 \mathrm{~g}$ sodium tungstate $\left(\mathrm{Na}_{2} \mathrm{WO}_{4} \cdot 2 \mathrm{H}_{2} \mathrm{O}\right)$ (Merck) is dissolved in $90 \mathrm{ml}$ distilled water. Reagent $\mathrm{A}$ is stored in a polyethylene bottle at room temperature.

Reagent $B$ : Phosphotungstic acid solution (Brocades, the Netherlands).

This reagent may be prepared as follows:

$500 \mathrm{~g}$ of sodium tungstate $\left(\mathrm{Na}_{2} \mathrm{WO}_{4} \cdot 2 \mathrm{H}_{2} \mathrm{O}\right), 400 \mathrm{ml} 85$ percent o-phosphoric acid and $3750 \mathrm{ml}$ distilled water are refluxed for two hours. After cooling $5 \mathrm{ml}$ bromine is added and the surplus of bromine is boiled out. After cooling the solution is diluted to a volume of 51 with distilled water. Kept in a brown bottle and stored in a refrigerator the reagent is stable for months.

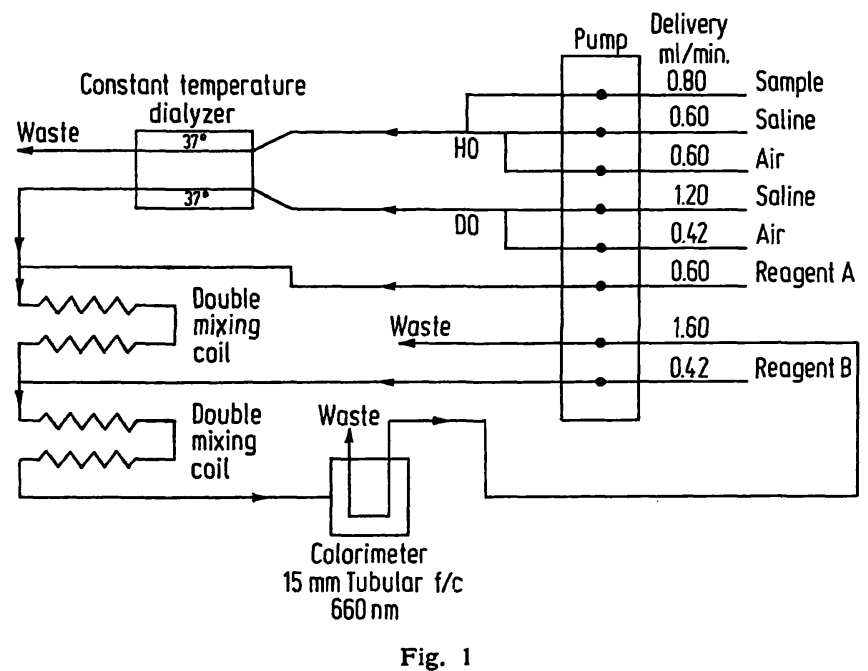

Flow diagram for the automated determination of uric acid. Labels refer to standard Auto Analyzer tygon pump tubing sizes and fittings. The usual pump rate is 40 per $h$

Saline: $9.0 \mathrm{~g}$ sodium chloride is dissolved in $1000 \mathrm{ml}$ distilled water, $0.5 \mathrm{ml}$ Aerosol 22 (Technicon) is added and the whole is mixed. The saline is stored in a polyethylene bottle.

Stock uric acid standard $(6.0 \mathrm{mmol} / \mathrm{l})$

$1.000 \mathrm{~g}$ uric acid (Merck) and $0.6 \mathrm{~g}$ lithium carbonate are placed in a 1 liter volumetric flask. $150 \mathrm{ml}$ distilled water is added and the whole is dissolved at a temperature of $60^{\circ}$. After cooling the solution is diluted to volume. The stock standard is stable for months if kept in a refrigerator.

\section{Working uric acid standards}

The stock uric acid standard is diluted with distilled water to the following concentrations: $0.15 ; 0.30 ; 0.45 ; 0.60$ and $0.90 \mathrm{mmol} / \mathrm{l}$. The working standards are stable for several weeks if kept in a refrigerator.

\section{Results}

Influence of other compounds

The eventual effects of interference in the colour reaction by a range of organic and inorganic compounds, added 
to serum and urine (diluted $1: 10$ ), were investigated. Inorganic phosphate, creatinine, urea, glucose, glycine, salicylate and bilirubin did not interfere, even when their concentrations were extravagantly high. Other compounds like ascorbic acid and cysteine interfered when their concentrations were more than moderately increased (see table 1).

Tab. 1

Compounds which were added to serum and urine (diluted $1: 10$ ) in the given concentrations did not interfere the colour reaction

\begin{tabular}{lc} 
Compound & $\begin{array}{c}\text { Concen- } \\
\text { tration } \\
{[\mathrm{mmol} / \mathrm{l}]}\end{array}$ \\
\hline inorganic phosphate & 2.50 \\
creatinine & 0.40 \\
urea & 20.0 \\
glucose & 22.0 \\
glycine & 1.25 \\
sodium salicylate & 7.00 \\
bilirubin & 0.17 \\
ascorbic acid & 0.12 \\
cysteine & 0.25 \\
\hline
\end{tabular}

\section{BEER'S law}

The colour produced in this method follows BEER's law up to a concentration of $1.20 \mathrm{mmol} / \mathrm{l}$ uric acid, and a straight line is obtained (fig. 2).

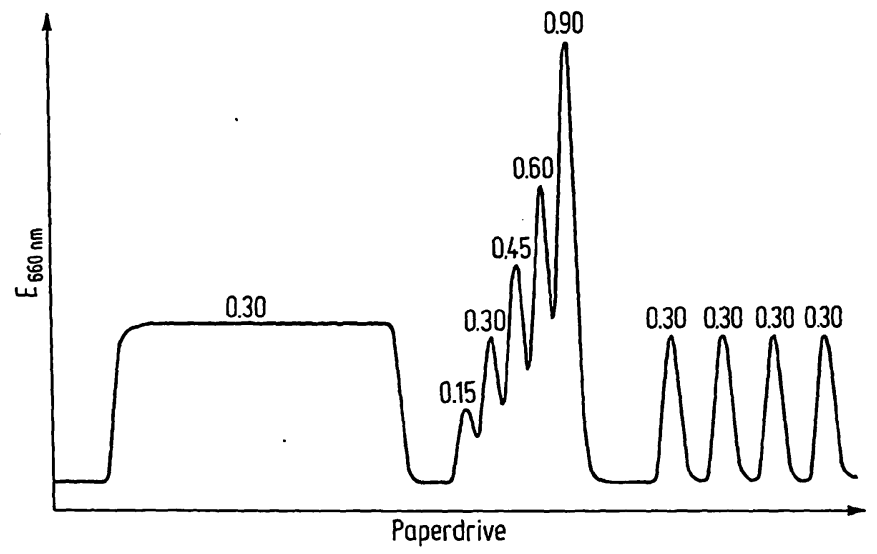

Fig. 2

Strip chart recording of procedure illustrating (a) a stable baseline (b) the absence of noise level during continuous aspiration of a standard solution of $0.30 \mathrm{mmol} / 1$ (c) standards in ascending order: the values are given in mmol/l, (d) reproducibility of several analyses performed on a single $0.30 \mathrm{mmol} / 1$ standard

In the concentration range of $1.20-1.80 \mathrm{mmol} / \mathrm{l}$ uric acid a slightly curved line is obtained.

\section{Recovery tests}

To serum and urine (diluted $1: 10$ ) (twenty specimens), standard solutions of uric acid in concentrations of $0.30 \mathrm{mmol} / 1$ and $0.60 \mathrm{mmol} / 1$ were added.

For urine, recoveries from 98 to $102 \%$ were found with the mean at $100 \%$.

The percentage recovery in serum ranged from $97^{\circ}$ to $100 \%$ of the uric acid added, with the mean at $99 \%$.

\section{Baseline drift and noise level}

The change in the baseline, measured over one hundred determinations, was found to be less than $0.5 \%$ transmission. The noise level was checked by continually aspirating a standard solution of $0.30 \mathrm{mmol} / 1$ and was found to be zero over a period equal to fifty determinations (fig. 2).

\section{Specimen interaction}

Specimen interaction is inherent in Auto Analyzers. Basically it is due to longitudinal mixing in the liquid stream. The colour peak, produced by a sample, tends to run into the peak produced by the sample immediately following it. This can be expressed in the carry over $i$. e. $\%$ carry over $=\frac{A_{2}-A_{1}}{A_{1}} \cdot 100$, where $A_{2}$ is the value of the second peak and $A_{1}$ the value of the first peak. The carry over can be influenced by the sample period/wash period ratio.

In this determination of uric acid, with a sample rate of 40 per $h$, the average carry over was found to be $1.4 \%$.

\section{Standard deviation and sensitivity}

Standards were run under conditions giving negligible carry over and a standard deviation was calculated from fifty determinations $(\mathrm{N}=50)$ (all standard solutions of $0.60 \mathrm{mmol} / \mathrm{l})$.

In this series a standard deviation of $1.6 \%$ was found (table 2).

Day to day precision was estimated, using a commercial control prepared from human blood (Monitrol I, Dade). In a series of 200 determinations $(N=200)$ an average value of $0.32 \mathrm{mmol} / \mathrm{l}$ was found with a standard deviation of $0.048 \mathrm{mmol} / 1$.

The ranges given by Dade were $0.30-0.32 \mathrm{mmol} / \mathrm{l}$ with an average value of $0.31 \mathrm{mmol} / \mathrm{l}$.

The sensitivity is adequate in that each $0.5 \%$ transmission line represents $0.006 \mathrm{mmol} / 1$ uric acid.

Tab. 2

Data for the calculation of the standard deviation

\begin{tabular}{|c|c|c|c|}
\hline $\mathbf{N}$ & $\overline{\mathbf{x}}$ & $s=\sqrt{\frac{\left(x_{i}-\bar{x}\right)^{2}}{n-1}}$ & $\frac{s \cdot 100}{\bar{x}}$ \\
\hline 50 & $0.60 \mathrm{mmol} / 1$ & $\pm 0.0096 \mathrm{mmol} / \mathrm{l}$ & $1.6 \%$ \\
\hline
\end{tabular}

\section{Normal values}

For the estimation of the normal range, frequency distributions were made from data obtained from 500 men and 532 women, whose serum uric acid levels were expected not to deviate from the normal area.

The normal ranges were calculated by the method of the $\%$ cumulative frequency curve $(2.5 \%-97.5 \%)$ (6). In the population of women $0.21-0.41 \mathrm{mmol} / \mathrm{l}$ was found to be normal with an average value of $0.31 \mathrm{mmol} / 1$ (table 3, fig. 3). In the population of men 0.25 to $0.45 \mathrm{mmol} / \mathrm{i}$ was found with an average value of 
Tab. 3

Data obtained from a population of 532 women and $\mathbf{5 0 0}$ men for the determination of the normal range for uric acid levels

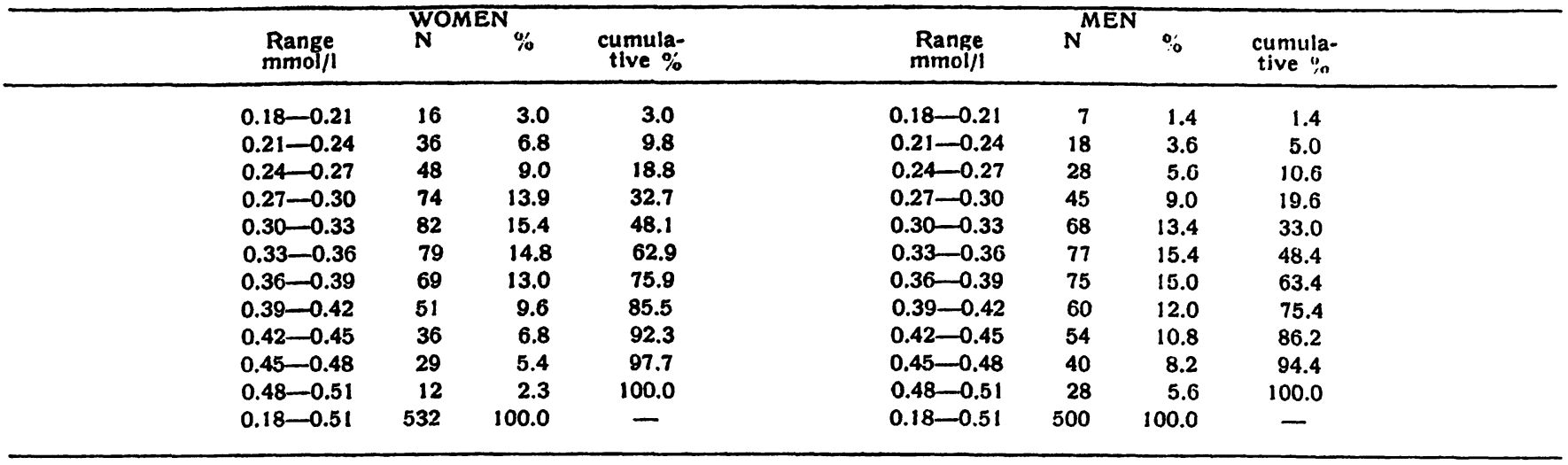

Tab. 4

Data for the calculation of $t$ according to the STUDENT test

\begin{tabular}{|c|c|c|c|c|c|}
\hline $\mathbf{N}$ & $\underset{\mathrm{mmol} / \mathrm{l}}{\overline{\mathrm{x}}}$ & $\underset{\mathrm{mmol} / \mathrm{l}}{\mathrm{s}}$ & $r_{\bar{x}_{2}-\bar{x}_{2}}=s \sqrt{\frac{1}{N_{1}}+\frac{1}{N_{2}}}$ & $t=\frac{\bar{x}_{1}-\bar{x}_{1}}{r_{\bar{x}_{1}}-\bar{x}_{2}}$ & $\mathbf{p}$ \\
\hline $\begin{array}{l}\text { Men } 500 \\
\text { Women } 500\end{array}$ & $\begin{array}{l}0.35 \\
0.31\end{array}$ & $\begin{array}{l}0.05 \\
0.05\end{array}$ & $3.16 \quad 10^{-2}$ & 12.6 & $<0.001$ \\
\hline
\end{tabular}

$0.35 \mathrm{mmol} / 1$ (table 3, fig. 4). These different normal ranges for men and women were found to be significant $(p<0.001)$ according to the STUDENT test (table 4).

\section{Discussion}

All colorimetric methods of uric acid determination are based on the reduction of phosphotungstate to a coloured phosphotungstite complex in an alkaline medium. The methods differ primarily in type of alkali used. Mostly sodium cyanide is used to intensify the colour of the phosphotungstite complex (7).

This procedure however has several objections: the extreme toxicity of cyanide, the high blanks, the development of turbidities if the cyanide solution is not freshly prepared, and the influence of amino acids on the colour produced $(4,8)$.

Methods based on other types of alkaline medium have been adapted to the Auto Analyzer and reported. As alkaline media are used carbonate (8), the "ARCHIBALD method" (9), sodium hydroxide (10) and EDTA-hydrazine (11).

All these methods have some disadvantages of their own. The recommended rate of analysis in the carbonate method only produces twenty results per hour and the sensitivity is poor. Turbidity problems occuring in the "ARCHIBALD method" have been reported (10) and the influence of other reducing substances have not been mentioned.

In the sodium hydroxide method neither the influence of any disturbing compound nor recovery tests were described.

The influence of other compounds (ascorbic acid and cysteine) in the EDTA-hydrazine method is greater than in the procedure described in this paper and

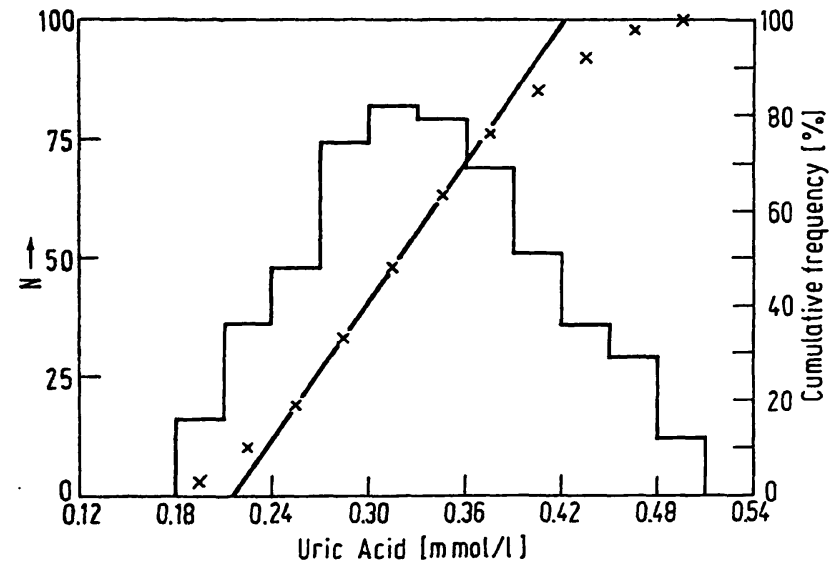

Fig. 3

Frequency distribution curve of normal values of uric acid obtained from 532 women. As normal range, calculated from the \% cumulative frequency curve $(2.5 \%-97.5 \%), 0.21-0.41 \mathrm{mmol} / 1$ was found, with an average value of $0.31 \mathrm{mmol} / \mathrm{l}$

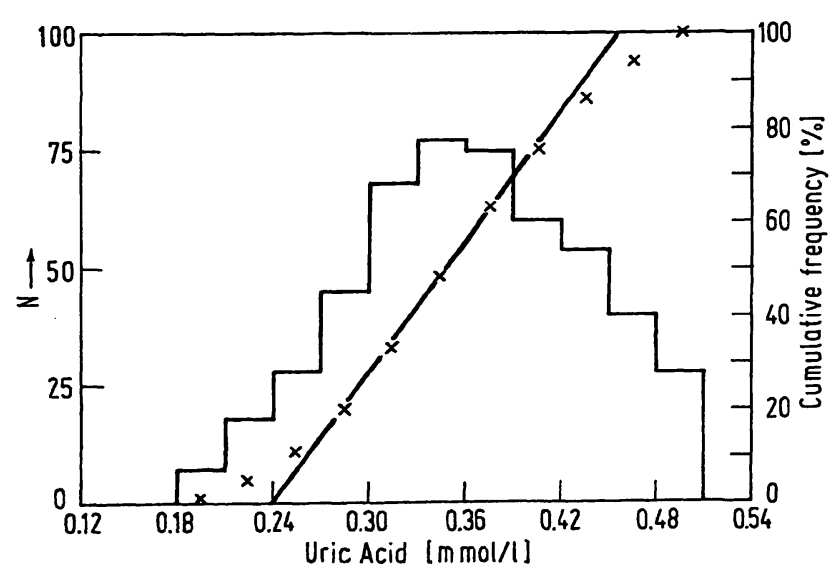

Fig. 4

Frequency distribution curve from data obtained from 500 men. As normal range, calculated from the \% cumulative frequency curve $(2.5 \%-97.5 \%), 0.25-0.45 \mathrm{mmol} / 1$ was found, with an average value 
some of the reagents have to be prepared freshly before use.

An automated enzymatic spectrophotometric method for the determination of uric acid has been reported (12). However, it requires more than a standard performance of the Auto Analyzer system, such as two proportioning pumps instead of one, a quartz flowcell, an U.V. spectrophotometer and the sampling rate is only thirty per hour.

Attempts to overcome the limitations of the above mentioned methods have led to the development of a simple and sensitive procedure suitable for toutine use.

\section{References}

1. Caraway, W. T., Standard Methods of Clinical Chemistry, Academic Press, New York. Vol. 4 p. 239 (1963). - 2. Henry, R. J., Clinical Chemistry Harper and Row., New York p. 276 (1966). - 3. Lous, P. and D. SyLvest, Scand. J. Clin. Laborat. Invest. 6, 40 (1954). - 4. Steel, A. E., Biochem. J. 68, 306 (1958). 5. Bennet, A., D. Gartelmand, J. I. Mason and J. A. Owen, Clin. Chim. Acta, Amsterdam 29, 161 (1970). - 6. Richterich, R., Klinische Chemie, Theorie und Praxis 2. Auflage. S. Karger,
Basel p. 17-45 (1968). - 7. "Uric Acid", Technicon Laboratory Method, File No. 13b. Technicon Instruments Corporation. 8. Croẅlex, L. V., Clin. Chem., New Yotk 10, 838 (1964). 9. Nishr, H. H., Clin. Chem., New York 13, 12 (1967). - 10. Wheat, J. L., Clin. Chem., New York, 14, 631 (1968). - 11. Patel, C. P., Clin. Chem., New York 14, 764 (1968). - 12. Steele, T. H., Amer. J. Clin. Path. 53, 116 (1970).

Ir. K. Breebaart and Dr. A. M. F. H. Haan Clinical laboratory, R. K. Ziekenhuis Mariastichting Kamperlaan 4

Haarlem

The Netherlands 
Für Ihr Gerinnungslabor
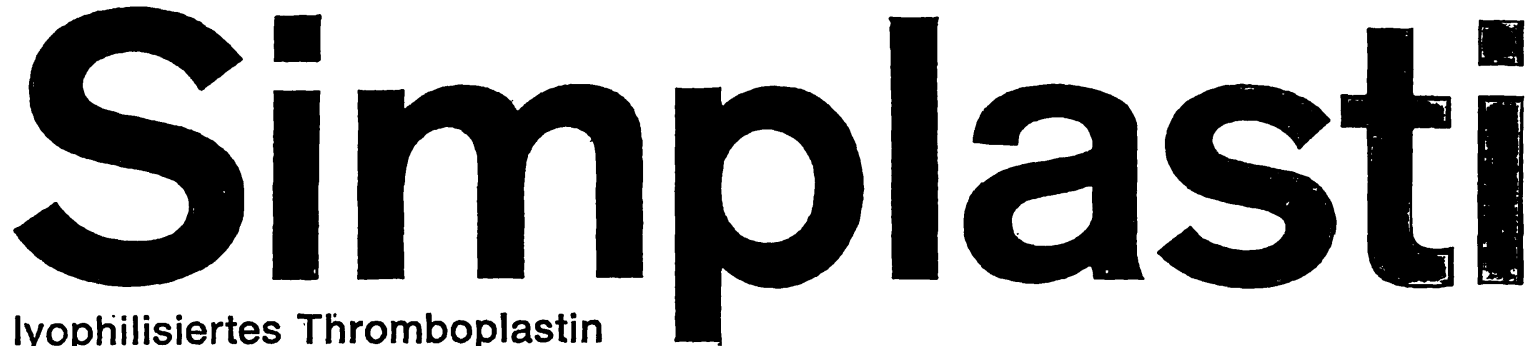

lyophilisiertes Thromboplastin

mit Calcium
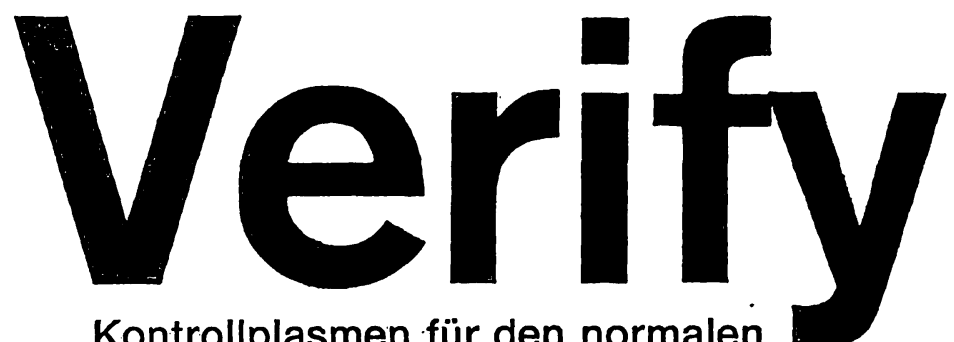

Kontrollplasmen für den normalen und therapeutischen Bereich

\section{Zur Bestimmung und Kontrolle der Th̆romboplastinzeit}

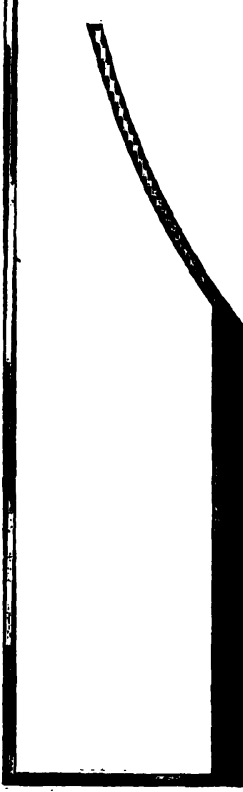

옹

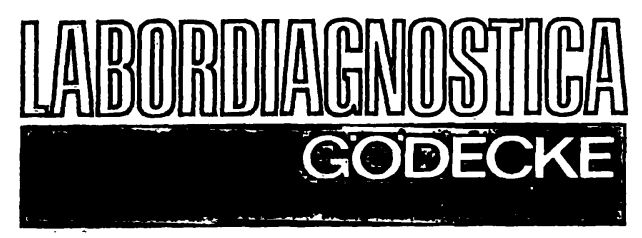

Vertrieb für Österreich:

Pharmazeutische Fabrik MONTAVIT GmbH

Vertrieb für die Schweiz:

Absam

Cosmopharm AG

Zimmerlistraße 6

A-6060 Solbad Hall (Tirol) 
Fragen Sie bei SIGMA nach

Ein-Reagenz- und Zwei-Reagenz-Systemen für die Bestimmung von

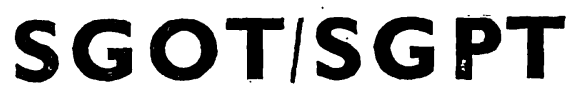

(Aspartat- + Alanin-Transaminase)

mit dem optischen Test in Serum oder anderen biologischen Flüssigkeiten bei $340 \mathrm{~nm}$

\section{„Stat", manuelle oder automatisierte kinetische' Verfahren}

Ein-Reagenz-System - Sigma Technical Bulletin Nr. 55-UV.

Ein schnelles, einfaches Verfahren für Routine- oder "Stat"bestimmungen von Hand oder mit automatisierten Systemen wie GEMSAEC. Centrifichem, Rotochem u. a., die mit nur einem Reagenz arbeiten. Sie brauchen nur Wasser und Serum hinzuzufügen und dann die Extinktion abzulesen; erhältlich sind entsprechend Ihren Erfordernissen Reagenzampullen für eine, fünf oder zehn Bestimmungen.

Das Sigma Technical Bulletin Nr. 55-UV erhalten Sie auf Anfrage gratis.

Bitte, bestellen Sie:

nummer amenzfür SG OT

Handels-
größen $\begin{gathered}\text { maximal } \\ \text { mögliche } \\ \text { Bestimmungen* }\end{gathered}$

10 mung

$55-5$

$55-10$ für 5 Bestim - 5 Ampullen für $10 \mathrm{Be}-\quad 5$ Ampullen stimmungen 10 Ampullen

\section{$5 \times 5$}

$10 \times 5$

$5 \times 10$

$10 \times 10$ mungen - 5 Ampullen

\section{| Lager- Reagenz- nummer ampullen} für SGPT
Handels- maximal Preis größen mögliche Bestimmungen* for SGPT 10 für 1 Bestim- 10 Ampullen $\quad 10 \$ 5,00$

$\$ 7,50 \quad 55-5 P \quad \begin{aligned} & \text { mung } \\ & \text { für } 5 \text { Bestim- } 5 \text { Ampullen } \quad 5 \times 5 \quad \$ 8,00\end{aligned}$ $\$ 14,85$ mungen 10 Ampullen $10 \times 5 \quad \$ 15,50$ $\$ 12,50 \quad 55-10$ für 10 Be- 5 Ampullen $5 \times 10 \quad \$ 14,00$ $\$ 24,85$ stimmungen 10 Ampullen $10 \times 10 \quad \$ 27,00$ *Die Reagenzampullen für die oben genannten Verfahren sind für $3 \mathrm{ml}$ Reaktionsvolumen ausgelegi. Da zahlreiche Geräte mil wesenflich weniger auskommen, kann die Anzahl der Bestimmungen pro Reagenzampulle entsprechend erhöht werden, wodurch sich der Preis pro Test erheblich reduziert.

Zwei-Reagenz-Systeme - Sigma Technical Bulletin Nr. 155-UV́.

Für autòmatisierte Analysengeräte, die für Zwei-Reagenz-Systeme ausgelegt sind, wie z. B. LKB Reaction Rate Analyzer und der Beckman DSA-560 und 564-B.

Kann ebenso für manuelle Verfahren und für automatisierte Analysengeräte, die mił nur einem Reagenz arbeiten, verwandt werden.

Das Sigma Technical Bulletin Nr. 155-UV erhalten Sie auf Anfrage gratis.

Bitte, bestellen Sie:

$\begin{array}{cccc}\text { Besteck-Nr. } & \begin{array}{c}\text { Art der } \\ \text { Bestimmung }\end{array} & \begin{array}{c}\text { maximal mögliche } \\ \text { Bestimmungen* }\end{array} & \text { Preis } \\ \text { 155-A } & \text { SGOT } & 100 & \$ 22,50 \\ 155-\mathrm{B} & \text { SGPT } & 100 & \$ 24,50 \\ \text { *Bezüglich der Anzahl der Bestimmungen siehe die oben gemachten Bemerkungen }\end{array}$

Natürlich bieten wir weiterhin das Original kolorimetrische Verfahren - erprobt in der ganzen Welt - überall imitiert, jedoch nie erreicht - an.

Nr. 505 - Sigma-Fränkel kolorimetrische Bestimmung Ferner ist erhältlich bei $490-530 \mathrm{~nm}$

Art der

Nr.410-UV -

Besteck-Nr.

- Bestimmung im
Art der
Bestimmung

optischen Test bei $340 \mathrm{~nm}$ Bestimmung mögliche

\begin{tabular}{llcr} 
& \multicolumn{3}{c}{ Bestimmungen } \\
505 & SGOT & 100 & $\$ 10,00$ \\
$505-M$ & SGOT & 25 & $\$ 5,50$ \\
$505-P$ & SGPT & 100 & $\$ 10,00$ \\
$505-P M$ & SGPT & 25 & $\$ 5,50$ \\
$505-O P$ & SGOT/SGPT & 100 & $\$ 15,00$ \\
& kombiniert & &
\end{tabular}

410-50 SGOT Bestimmungen

410-100

410-50P

410-OP

SGOT

SGPT

kombiniert

Preis

Sigma Technical Bulletins für die oben aufgeführten Methoden sind auf Anfrage gratis erhältlich.

Alle Preise einschließlich normaler Versandgebühr zu Ihnen überall hin in die Welt.

Es ist ein Vergnügen, Geschäfte mit Sigma zu machen

Bestellen Sie direkt - R-Gespräch von überall her in der Welt Tagsüber von Haus zu Haus, 314-771-5750. Nachts von Person zu Person, Dan Broida, 314-993-6418 TWX (Fernschreiber) Tag und Nacht: Rückantwort 910-761-0593

Sigma-Reagenzien sind in der ganzen Welt durch den Fachhandel oder direkt aus St. Louis beziehbar.

Telegramme: SIGMACHEM, St. Louis, Missouri

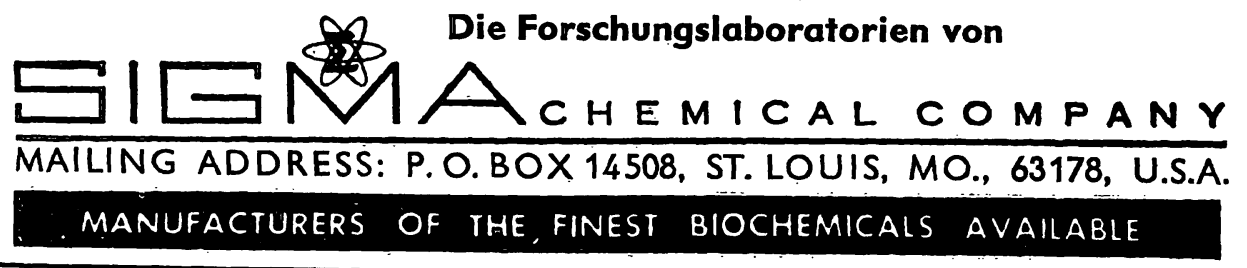

Vertreten durch

SIGMA LONDON Chem. Co. Ltd. • 12, Lettice St., London, S. W. 6., England Telephone: 01-736-5823 (Reverse Charges)

SIGMA ISRAEL Chem. Co. Ltd. 28 Kaf-Gimel St., Givataim, Israel Telephone: (03) 760654 (Reverse Charges) 